\title{
Eichornia Crassipes as Handicraft Materials and Energy Sources:
}

\section{A Contextual Learning Approach During the Covid-19 Pandemic}

\author{
Dindin Nasrudin ${ }^{1, *}$ Chaerul Rochman ${ }^{1}$, Ahmad Abtokhi $^{2}$, Iwan Permana Suwarna ${ }^{3}$, \\ Melati Fauziah $^{1}$
}

\author{
${ }^{1}$ Program Studi Pendidikan Fisika, UIN Sunan Gunung Djati Bandung, Indonesia \\ ${ }^{2}$ Program Studi Fisika, UIN Maulana Malik Ibrahim Malang, Indonesia \\ ${ }^{3}$ Program Studi Tadris Fisika, UIN Syarif Hidayatullah, Jakarta, Indonesia \\ *Corresponding author. Email: dindin.nasrudin@uinsgd.ac.id
}

\begin{abstract}
The existence of Eichornia crassipes plants is often regarded as a weed that can damage the aquatic environment. However, at this time, Eichornia crassipes can be made into handicraft materials and briquettes. This paper wants to reveal the physical concepts that exist in the process of making handicrafts and briquettes made from Eichornia crassipes. This research is a field study using observation, interviews and reinforced with literature studies. The results showed several physical concepts that can be revealed in making handicrafts and briquettes made from Eichornia crassipes, such as temperature, heat radiation, mechanical advantage. The process of making handicrafts and briquettes from Eichornia crassipes can be used as a source of contextual physics learning during the covid-19 pandemic.
\end{abstract}

Keywords: Eichornia crassipes, handicraft, energy sources

\section{INTRODUCTION}

Covid-19 has had a broad impact on the world of education, including learning physics. Physics learning, which was initially carried out classically on campus, must be changed to learning from home. Rapid and innovative efforts are needed to change the learning approach. Individual project-based learning is considered as an alternative solution to problem-solving. One example is turning hyacinth plants into handicraft materials and energy sources as a learning context. During this time, the existence of water hyacinth plants (Eichornia crassipes) is often regarded as a weed and disrupt the aquatic ecosystem and damage the environment [1],[2]. Even claimed to be included in the ten most problematic water weeds in the world [3]. Behind the problems caused, water hyacinth plants also have advantages. Besides being used for animal feed, the stems and leaves of water hyacinth can be used to develop supercapacitors and ethanol production [4]. Today the water hyacinth plant is also used as a substitute for fossil fuels and removes pollutants from domestic and industrial wastewater with bioremediation [5],[6].
Previous research shows that water hyacinth plants can also be used to produce biogas [7]. Water hyacinth that has been crushed and mixed with water in a ratio of 1: 2 can produce 34.7 liters of biogas from $20 \mathrm{~kg}$ of processed Eichornia crassipes. The content contained in this biogas is $58 \% \mathrm{CH}_{4}$ and $45 \% \mathrm{CO}_{2}$. The biogas produced is used as fuel for cooking, lighting, and as a water heater [8]. In addition, because it has a beautiful flower shape, water hyacinth is also considered to have a beautiful artistic or aesthetic value for the environment. Some people use water hyacinth as a material for making handicrafts.

By seeing the various potentials that can be developed from water hyacinth, increasing public literacy about the cultivation of water hyacinth and its utilization becomes important. One of the efforts to increase community literacy can be made by integrating the content and context of the use of water hyacinth into physics learning. The hope, students who are representatives of educated people, can implement it in everyday life. This paper wants to describe the process of making handicrafts and making briquettes from the basic ingredients of water 
hyacinth accompanied by an explanation of the physical concepts involved in it.

\section{METHOD}

This research is a field study that tries to explore as complete information as possible about a phenomenon. The main activity of this field study is direct observation and in-depth interviews with key informants. The results of observations and interviews were confirmed through literature studies.

Observation. Observation is the main method conducted by researchers. The reason is that researchers need information, processes, or direct discussions. In addition, researchers can also easily find physical evidence, products, or results needed [9]. Observation to learn how to directly process water hyacinth into handicrafts and energy sources. The study was conducted in a village in West Bandung, West Java province, Indonesia.

Interview. The results of the field observations were strengthened through in-depth interviews with key informants, some craftsmen who were directly involved in the process of water hyacinth processing. Interviews are indispensable to clarify some of the terms used at each stage while strengthening the results of observation. Interviews are important because they have become a window to the world of experience for researchers and professionals [10].

Literature studies. A literature study is carried out to confirm local terms at each processing step while adding references to discover the physical concepts involved in each processing process. Literature studies can contribute significantly to the systematic and additional development of each research domain [11].

\section{RESULTS AND DISCUSSION}

\subsection{Craft Making Process}

Raw Material Supply. The supply of raw materials for making water hyacinth handicrafts in this village comes from residents who are used to collecting water hyacinth. Usually, the collection of raw materials is adjusted to the order and availability of water hyacinth in the river. Figure 1 shows each stage of making handicraft materials from water hyacinth.

Drying. After supplying the raw materials, the wet water hyacinth will pass through the drying for one week when the weather is indeed hot and consistent. However, during the rainy season, where the sun's heat intensity decreases, more time is needed for the drying process. The average time needed for the wet water hyacinth to be ten days or two weeks for the water hyacinth to become dry.

Cutting. After the drying process, the water hyacinth will be cut according to the type of handicraft that will be made. Manual cutting usually uses scissors and a knife as the main tool.

Weaving. Weaving is the most complex step. Required special expertise and high artistic spirit. It is in the hands of the weavers that a form of handicraft will be produced. To get products that have a high artistic taste,

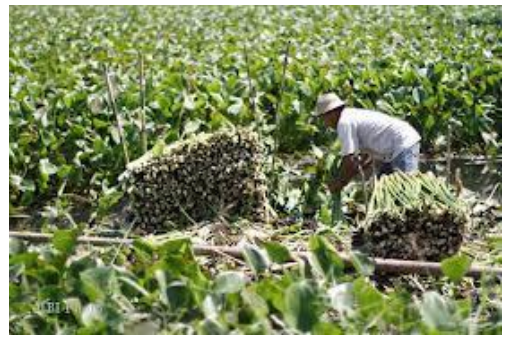

(a)

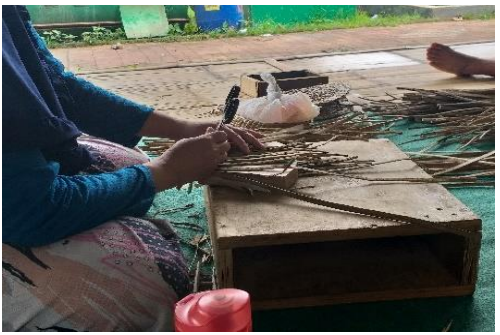

(d)

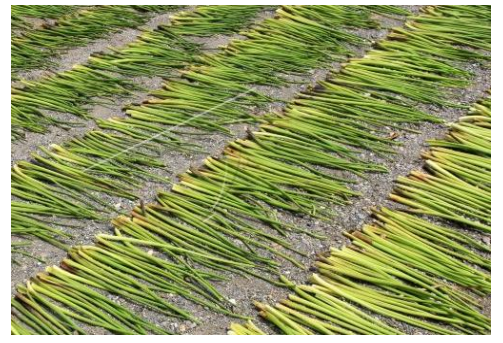

(b)

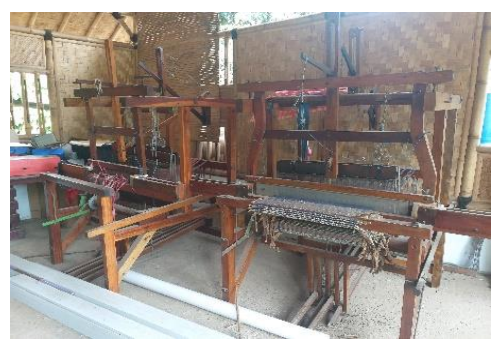

(e)

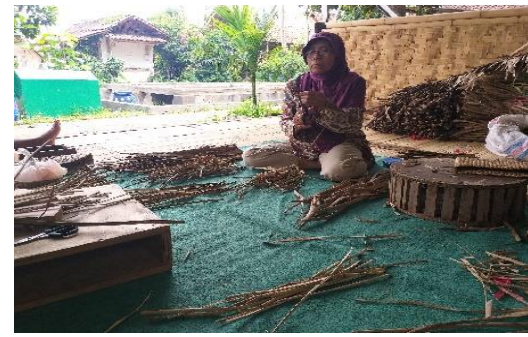

(c)

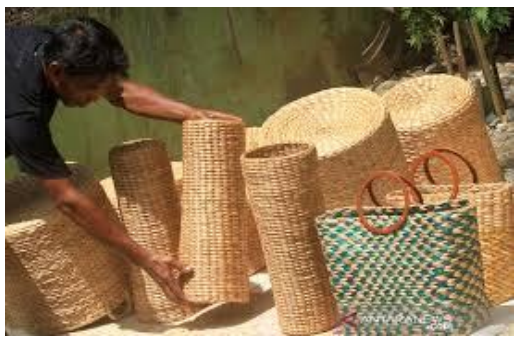

$(f)$

Figure 1 The process of making Eichornia crassipes into handicraft (d) weaving; (e) semi-finished material; (f) finished material (craft).

(a) raw material; (b) drying; (c)cutting; 
some materials are painted in advance with various colors as desired.

\subsection{The Process of Making Briquettes Made from Eichornia Crassipes}

In practice in the field (research site), the use of water hyacinth plants as briquette making material only uses the remaining material that is not used for handicraft. Table 1 shows the complete process of processing water hyacinth plants into briquettes.

Some binders can be used, including cow dung and sawdust. The addition of cow dung and sawdust has been shown to increase the calorie value of briquettes that were developed [12]. Another binder is molasses. Increasing the amount of molasses as a briquette binder increases water content, volatile substances and maintains carbon levels while reducing ash content [13].

Biobriquette products from water hyacinth have several advantages, including being relatively easier to ignite than coal briquettes. The smell emitted from burning bio briquette is also not too pungent. However, the lower heating content of biomass causes the number of briquettes needed for the same needs to be relatively higher than coal and kerosene. This can be overcome by carbonization techniques and regulating volatile content to increase the calorific value of the water hyacinth bio brackets. Although the use of water hyacinth briquettes takes longer for cooking purposes compared to kerosene stoves, better cooking time can be obtained when the water hyacinth briquette is assisted with several pieces of wood [14].

The essential properties of bio briquettes that affect fuel quality are physical and chemical. The physical properties of bio briquettes can be obtained from the manufacturing process, from the selection of materials to the results in the form of bio briquettes that are ready for use. The particle size of charcoal also influences the quality of bio briquettes. Charcoal produced from the carbonization of water hyacinth plants is considered quite good. As a result, the production of water hyacinth briquettes qualifies as an alternative energy source because it is cheaper and environmentally friendly [15],[16].

\subsection{Physical Concept in the process of making handicrafts and water hyacinth briquettes}

There are several physical concepts that can be discussed in the process of making water hyacinth handicrafts and briquettes. The concepts will be analyzed below.

In the drying process, the intensity of sunlight and ambient temperature are very influential on the speed of the process of drying water hyacinth. The radiation received by water hyacinth from the environment is formulated by the formula:

$$
P_{a b s}=\sigma \varepsilon A T_{e n v}^{4}
$$

Where $\mathrm{P}_{\mathrm{abs}}=$ heat flow rate, $\sigma=5.6703 \times 10^{-8} \mathrm{~W} / \mathrm{m}^{2}$. $\mathrm{K}^{4}$, is called the Stefan-Boltzmann constellation, $\varepsilon=$ surface emissivity (value from 0 to 1 ). $\mathrm{T}_{\mathrm{env}}=$ is the ambient temperature (Kelvin) [17].

When water hyacinth is cut using scissors, there is a physics concept about the use of simple aircraft. Scissors are included in simple type I aircraft. The mechanical advantages of shears are formulated by:

$$
M A=\frac{\text { Effort arm }}{\text { load arm }}
$$

with a mechanical advantage of less than 1 .

Table 1. The process of making briquettes from water hyacinth

\begin{tabular}{|c|l|l|}
\hline No. & \multicolumn{1}{|c|}{ Stages } & \multicolumn{1}{c|}{ Explanation } \\
\hline 1 & $\begin{array}{l}\text { Processing materials } \\
\text { into charcoal }\end{array}$ & $\begin{array}{l}\text { Water hyacinth is cleaned from dirt by using clean water. Water hyacinth } \\
\text { that has been cut into small pieces is dried in the sun or using a heater } \\
\text { if in the rainy season. The process of making water hyacinth can use a } \\
\text { furnace. After being removed from the furnace, the water hyacinth } \\
\text { biomass is mashed and then sieved. }\end{array}$ \\
\hline 2 & $\begin{array}{l}\text { The process of mixing } \\
\text { charcoal with binders }\end{array}$ & $\begin{array}{l}\text { Biomass from the sifting process is then added to the binders that has } \\
\text { been prepared with a certain ratio. Biomass and binders are stirred until } \\
\text { everything is mixed evenly. }\end{array}$ \\
\hline 3 & Biobriquette printing & $\begin{array}{l}\text { The bio briquette material that has been mixed is put into the bio } \\
\text { briquettes printer. The bio briquettes are oven-dried at a certain } \\
\text { temperature and time. Biobriquette is removed from the oven and } \\
\text { allowed to cool. }\end{array}$ \\
\hline
\end{tabular}


At the time of making briquettes from water hyacinth, several physical quantities can be discussed, including relaxation ratio, percentage water, and burning rate $[18,19]$. Relaxation ratio has calculated the ratio of compressed density to relaxed density

relaxation ratio $=\frac{\text { compressed density }}{\text { relaxed density }}$

The percentage of water gain was calculated using the following relationship:

$$
\% \text { water gained by briquette }=\frac{M_{2}-M_{1}}{M_{1}}
$$

where $M 1$ is the Initial weight of the briquette before immersion and $M 2$ is the final weight of the briquette after immersion. The weight loss at a specific time was computed from the expression:

$$
\text { burning rate }=\frac{\text { total weight of the burnt briquette }}{\text { total time taken }}
$$

\subsection{Using the topic of water hyacinth cultivation around the neighborhood as a learning context}

The implementation of quarantine during the Covid19 period has opened up various strategies and approaches focused on the education model from home. These fashion changes or transitions sometimes do not consider economic, social, and technological inequalities [20]. A breakthrough in learning approaches that are friendly to students (pedagogically) and pleasant to parents (economically), and not burdensome in technological adaptation is needed. Open Educational Resources (OER) and Open Educational Practice (OEP) can be used as effective educational solutions to address academic challenges during the Covid-19 pandemic [21]. One example is using project-based learning by raising activities around houses such as processing water hyacinth into crafts and energy sources carried out by a group of farmers in West Java, Indonesia. Students can observe and participate in each stage, interview them, and make a complete report.

\section{CONCLUSION}

The existence of the water hyacinth plant (Eichornia crassipes) can become a craft material and a source of renewable energy (briquettes) with certain processing. Many physics concepts can be raised and discussed from every stage of making handicrafts and briquettes made from water hyacinth. Through a project-based learning approach and the use of Open Educational Resources (OER) and Open Educational Practice (OEP), the processing of water hyacinths into handicrafts and briquettes can be used as a context for learning physics during the Covid-19 pandemic.

\section{REFERENCES}

[1] T. A. E. G. El-Shahawy, M. A. Khater, F. A. Sharara, Eco-genetic study on water hyacinth, Eichhornia crassipes (Mart.) Solms, the world's most invasive aquatic plant. Agricultural Engineering International: CIGR Journal vol. 19, 2018, pp. 69-79.

[2] K. N. Nwaigwe, U. C. Egbufor, S. N. Asoegwu, C. C. Enweremadu, Potentials for Utilization of Water Hyacinth in Biogas Production: An Environmental Management Practice in Coastal Areas. Environmental Research Journal, Nova Science Publishers, Inc, vol. 11, 2017

[3] T. F. Rakotoarisoa, T. Richter, H. Rakotondramanana, J. Mantilla-Contreras, Turning a problem into profit: Using Water Hyacinth (Eichhornia crassipes) for making handicrafts at Lake Alaotra, Madagascar. Economic Botany, vol. 70, 2016, pp 365-379. DOI: https://doi.org/10.1007/s12231-016-9362y

[4] V. Guna, M. Ilangovan, M. G. A. Prasad, N. Reddy, Water Hyacinth: A Unique Source for Sustainable Materials and Products, ACS Sustainable Chem. Eng. Vol.5, 2017, pp. 4478-4490 DOI: https://doi.org/10.1021/acssuschemeng.7b0005 $\underline{1}$

[5] S. Rezania, M. Ponraj, M. F. M. Din, A. R. Songip, F. M. Sairan, S. Chelliapan, The diverse applications of water hyacinth with main focus on sustainable energy and production for new era: An overview, Renewable and Sustainable Energy Reviews, vol. 41, 2015, p. 943-954 DOI: https://doi.org/10.1016/j.rser.2014.09.006

[6] J. Milke, M. Gałczynska, J. Wróbel, The Importance of Biological and Ecological Properties of Phragmites Australis (Cav.) Trin. Ex Steud., in Phytoremendiation of Aquatic Ecosystems-The Review, Water, vol. 12, 2020 p.

1770 ,

DOI: https://doi.org/10.3390/w12061770

[7] P. Priya, S. O. Nikhitha, C. Anand, R. S. Dipin Nath, B. Krishnakumar, Biomethanation of water hyacinth biomass, Bioresource Technology, 2018, DOI: https://doi.org/10.1016/j.biortech.2018.01.119

[8] V. P. Rathod, P. V. Bhale, R. S. Mehta, K. Harmani, S. Bilimoria, A. Mahida, H. Champaneri, Biogas Production from Water Hyacinth in the Batch type Anaerobic Digester, in Materials Today: Proceedings, vol.5, 2018 , 
p.

23346-23350,

DOI:

https://doi.org/10.1016/j.matpr.2018.11.072

[9] E. Taylor-Powell, S. Steele, Collecting evaluation data: Direct observation, Program Development and Evaluation, Wiscounsin: University of Wisconsin-Extension, 1996 p.17.

[10] J. F. Gubrium, J. A. Holstein, Handbook of interview research: Context and method, Sage Publications, 2001.

[11] W. Bandara, S. Miskon, E. Fielt, A systematic, tool-supported method for conducting literature reviews in information systems. In M Rossi, J Nandhakumar (Eds.) ECIS 2011 Proceedings [19th European Conference on Information Systems], AIS Electronic Library (AISeL) / Association for Information Systems, 2011, p. 1-13. http://aisel.aisnet.org/

[12] R. Baidya, T. Bhattacharya, G. Kumar, S. K, Ghosh, Energy Analysis of Water HyacinthCow Dung-Sawdust Mixture Briquettes-An Indian Perspective. In: Ghosh S. (eds) Waste Management and Resource Efficiency. Springer, Singapore, 2019, DOI: https://doi.org/10.1007/978-981-10-7290-1_60

[13] N. P. Carnaje, R. B. Talagon, J. P. Peralta, K. Shah, J. Paz-Ferreiro, Development and characterisation of charcoal briquettes from water hyacinth (Eichhornia crassipes)-molasses blend, PLoS ONE, vol.13, 2018, DOI: https://doi.org/10.1371/journal.pone.0207135

[14] Z. Zoukumor, K. Odu, O. A. Ighodalo, C. Egbon, S. Okoh, Processing water hyacinth into biomass Briquettes for cooking purposes, Journal of Emerging Trends in Engineering and Applied Sciences vol.2, p. 305-307.
[15] R. M. Davies, O. A. Davies, Physical and Combustion Characteristics of Briquettes Made from Water Hyacinth and Phytoplankton Scum as Binder, Hindawi Publishing Corporation Journal of Combustion, 2013, DOI: http://dx.doi.org/10.1155/2013/549894

[16] S. Rezania, M. F. Din, S. F., Kamaruddin, S. M., Taib, L., Singh, E. L. Yong, F. A. Dahalan, Evaluation of water hyacinth (Eichhornia crassipes) as a potential raw material source for briquette production, Energy, vol. 111, 2016 p. 768-773.

DOI: https://doi.org/10.1016/j.energy.2016.06.026

[17] D. Halliday, Resnick, R. Walker, Physic, 7th extended edition, John Willey \& Sons, 2010

[18] A. I. Bamgboye, S. J. Bolufawi, Physical Characteristcs of Briquettes from Guinea corn (sorghum bi-color) Residue, Agricultural Engineering International: CIGR Journal, 2009

[19] A. Olorunnisola, Production of fuel briquettes from waste paper and coconut husk admixtures, International Commission of Agricultural Engineering (CIGR, Commission Internationale du Genie Rural) E-Journal vol.9, 2007

[20] R. Huang, A. Tlili, T. Chang, Disrupted classes, undisrupted learning during COVID-19 outbreak in China: application of open educational practices and resources, Smart Learning Environments, vol. 7, 2020, DOI https://doi.org/10.1186/s40561-020-00125-8

[21] L. Bonilla-Molina, Covid-19 on Route of the Fourth Industrial Revolution, Postdigital Science and Education, vol.2, 2020, p. 562-568 DOI: https://doi.org/10.1007/s42438-020$\underline{00179-4}$ 